\title{
PENGELOLAAN ASET PEMERINTAH DAERAH DALAM PERSPEKTIF GOOD GOVERNANCE
}

\author{
Donna Okthalia Setiabudhi ${ }^{1}$ \\ ${ }^{1}$ Program Studi Ilmu Hukum, Fakultas Hukum, Universitas Sam Ratulangi, Jl. Kampus Bahu, Manado, 95115, \\ Indonesia \\ E-mail koresponden : donna_setiabudhi@yahoo.com
}

\begin{abstract}
ABSTRAK
Tujuan penelitian adalah mengetahui peran pengelolaan asset pemerintah kabaputen Kepulauan Sangihe terhadap pembangunan dan mengetahui konstruksi hokum yang ideal pengelolaan asset pemerintah sehingga dapat mencerminkan penyelenggaraan pemerintahan yang baik. Penelitian ini diarahkan pada kekhasan ilmu hukum yang sifatnya normatif sehingga tipe penelitian ini adalah penelitian hukum normatif, yaitu penelitian yang mengkaji ketentuan hukum positif tertulis secara sistematis terkait dengan pengelolaan asset pemerintah daerah. Hasil penelitian menunjukkan bahwa Peran Barang Milik Daerah adalah untuk menghasilkan keuntungan melalui beberapa kontribusi sesuai dengan metode pemanfaatan asset, memaksimalkan manfaat dari sumber daya barang milik daerah agar tujuan penyelenggaraan pemerintahan daerah tercapai. Konstruksi hukum yang ideal pengaturan pengelolaan asset daerah yang mencerminkan asas pemerintahan yang baik adalah substansi hokum yang harmonis dengan Peraturan Pemerintah No. 27 Tahun 2014 dengan tidak mengesampingkan kondisi khusus dari daerah setempat sehingga Peraturan Daerah yang dibentuk adalah peraturan daerah yang memenuhi dua kedudukan yaitu sebagai local legislation dan subordinary legislation.
\end{abstract}

Kata kunci : pengelolaan; aset pemerintah daerah; good governance

\section{PENDAHULUAN}

Pemerintahan Daerah merupakan salah satu substansi dalam konstitusi Negara Republik Indonesia sebagaimana ditegaskan dalam Pasal 18 ayat (2) UUD 1945, bahwa pemerintahan daerah provinsi, daerah kabupaten, dan kota mengatur dan mengurus sendiri urusan pemerintahan menurut asas otonomi dan tugas pembantuan. Pemerintahan daerah menjalankan otonomi seluas-luasnya, kecuali urusan pemerintahan yang oleh undang-undang ditentukan sebagai urusan Pemerintah Pusat (Pasal 18 ayat (5) UUD 1945). Dasar hukum pembentukan Peraturan Daerah dalam Undang- undang Nomor 23 Tahun 2014 tentang Pemerintahan Daerah merupakan dasar hukum pembentukan peraturan daerah diatur dalam Pasal 236 sebagai berikut :

1. Untuk menyelenggarakan Otonomi Daerah dan TugasPembantuan, Daerah membentuk Perda.

2. Perda sebagaimana dimaksud pada ayat (1) dibentuk oleh DPRD dengan persetujuan bersama kepala Daerah.

3. Perda sebagaimana dimaksud pada ayat (1) memuat materi muatan: (a) penyelenggaraan Otonomi Daerah dan Tugas Pembantuan; dan (b) penjabaran lebih lanjut ketentuan peraturan perundang-undangan yang lebih tinggi.

4. Selain materi muatan sebagaimana dimaksud pada ayat (3) Perda dapat memuat materi muatan lokal sesuai dengan ketentuan peraturan perundang-undangan.

Daerah provinsi dan Daerah kabupaten/kota mempunyai Urusan Pemerintahan masing-masing yang sifatnya tidak hierarki, namun tetap akan terdapat hubungan antara 
Pemerintah Pusat, Daerah provinsi dan Daerah kabupaten/kota dalam pelaksanaannya . Di samping urusan pemerintahan Esensi dari otonomi daerah memberikan adalah memberikan kewenangan kepada daerah. ${ }^{1}$

Penyelenggaraan pemerintahan negara dan pemerintahan daerah yang efektif dan efisien sangat membutuhkan tersedianya sarana dan prasarana yang memadai yang terkelola dengan baik dan efisien. Untuk mendukung pengelolaan aset daerah secara efisien dan efektif serta menciptakan transparansi kebijakan pengelolaan aset daerah, maka pemerintah daerah perlu memiliki dasar hukum dalam bentuk Peraturan Daerah sebagai dasar hukum dalam pengaturan tentang pengelolaan barang milik daerah.

Perkembangan pengaturan dalam bentuk Peraturan pemerintah No 27 Tahun 2013 tentang Pengelolaan Barang Milik Negara / Daerah megatur tentang ada kewenangan pemerintah daerah untuk menetapkan kebijakan terkait dengan pengelolaan barang milik daerah Pembagian urusan pemerintahan konkuren antara Daerah provinsi dengan Daerah kabupaten/kota walaupun Urusan Pemerintahan sama, perbedaannya akan nampak dari skala atau ruang lingkup urusan pemerintah tersebut. Dalam Pasal 28 Undang-Undang No 1 Tahun 2004 tentang Perbendaharaan Negara mengatur bahwa :

1. Pokok-pokok mengenai pengelolaan uang negara/daerah diatur dengan peraturan pemerintah setelah dilakukan konsultasi dengan bank sentral.

2. Pedoman lebih lanjut mengenai pengelolaan uang negara/daerah sesuai dengan ketentuan yang diatur dalam peraturan pemerintah sebagaimana dimaksud pada ayat (1) ditetapkan oleh Menteri Keuangan selaku Bendahara Umum Negara.

3. Pelaksanaan ketentuan sebagaimana dimaksud pada ayat (2) yang berkaitan dengan pengelolaan uang daerah selanjutnya diatur dengan peraturan daerah.

Dasar-dasar kewenangan pengaturan antara laindasar kewenangan atribusi dan kewenangan delegasi. Antara atribusi dan delegasi terdapat persamaaan dan perbedaan. Persamaannya adalah lembaga yang menerima wewenang bertanggungjawaban atas pelaksanaan wewenang itu. Perbedaannya adalah pada delegasi selalu didahului oleh adanya atribusi, sedangkan dalam atribusi tidak ada yang mendahului, pada atribusi terjadi pembentukan wewenang sedangkan pada delegasi terjadi penyerahan wewenang. ${ }^{2}$

Terkait dengan pengelolaan barang milik daerah dalam Pasal 28 ayat (1) UndangUndang No 1 Tahun 2004 tentang Perbendaharaan Negara memberikan dasar kewenangan terkait dengan delegasi pengaturan dalam Peraturan Pemerintah No 27 Tahun 2014 tentang Pengelolaan Barang Milik Negara/Daerah. Dalam Pasal 5 Peraturan Pemerintah tersebut mengatur bahwa:

1. Gubernur/Bupati/Walikota adalah pemegang kekuasaan pengelolaan Barang Milik Daerah.

2. Pemegang kekuasaan pengelolaan Barang Milik Daerah berwenang dan bertanggung jawab : (a) menetapkan kebijakan pengelolaan Barang Milik Daerah; (b) menetapkan Penggunaan, Pemanfaatan, atau Pemindahtanganan Barang Milik Daerah berupa tanah dan/atau bangunan; (c) menetapkan kebijakan pengamanan dan pemeliharaan Barang Milik Daerah; (d) menetapkan pejabat yang mengurus dan menyimpan Barang Milik Daerah; (e) mengajukan usul Pemindahtanganan Barang Milik Daerah yang memerlukan persetujuan Dewan Perwakilan Rakyat Daerah; (f) menyetujui usul Pemindahtanganan, Pemusnahan, dan Penghapusan Barang Milik Daerah sesuai batas kewenangannya; (g) menyetujui usul Pemanfaatan Barang Milik Daerah berupa sebagian tanah dan/atau

\footnotetext{
${ }^{1}$ Puteri Hikmawati. 2012. Sinkronisasi Dan hemonisasi Hukum Penyelenggaraan Otonomi Daerah Studi Di Provinsi Bali . Hlm. 5

${ }^{2}$ Ni Luh Gede Astariyani. 2009. Pendelegasian Kewenangan Mengatur Dalam Peraturan Gubernur. Tesis. program Pasca sarjana Universitas Udayana : Bali. Hlm. 41.
} 
bangunan dan selain tanah dan/atau bangunan; dan (h) menyetujui usul Pemanfaatan Barang Milik Daerah dalam bentuk Kerja Sama Penyediaan Infrastruktur.

Dalam Pasal 105 mengatur tentang Ketentuan lebih lanjut mengenai pengelolaan Barang Milik Daerah diatur dengan Peraturan Daerah berpedoman pada kebijakan pengelolaan Barang Milik Daerah sebagaimana dimaksud dalam Pasal 90 ayat (3). Pengelolaan barang milik daerah di Kabupaten kepulauan Sangihe selama ini didasarkan pada Peraturan Daerah Kabupaten Kepulauan Sangihe No 9 Tahun 2008 tentang Pengelolaan Barang Milik Daerah yang dibentuk berdasarkan pada Peraturan Menteri Dalam Negeri Nomor 17 Tahun 2007 tentang Pedoman Teknis Pengelolaan Barang Milik Daerah. Beberapa realitas dalam pengelolaan barang milik daerah di Kabupaten Kepualauan Sangihe adalah sebagai berikut : (a) belum adanya perencanaan pengadaan barang milik daerah yang dilaksanakan secara efektif dan efisien sehingga perencanaan pengadaan barang milik daerah kerap tidak sesuai dengan kebutuhan yang menyebabkan barang milik negara menjadi tidak efektif pemanfaatannya; (b) belum optimalnya legalisasi asset milik daerah sehingga banyak asset daerah khususnya yang berupa tanah yang tidak memiliki sertipikat bahkan dikuasai oleh pihak lain; (c) belum jelasnya jumlah barang milik daerah khususnya asset berupa tanah karena tidak dilakukan identifikasi dan pengawasan pengelolaan dan pemanfaatannya; (d) belum optimalnya pemanfaatan asset milik daerah sehingga belum sepenuhnya mampu memberikan andil yang besar terhadap pelaksanaan pembangunan daerah; (e) banyaknya asset pemerintah daerah yang tidak tercatat dalam daftar asset yang menyebabkan ketika terjadi permasalahan misalnya perkara, pihak pemerintah daerah kalah oleh pihak lain; (f) banyaknya asset pemerintah daerah yang sudah tidak terpakai dan rusak tetapi tidak dimusnahkan dan tidak dihapus sehingga menyebabkan ketidakseimbangan dalam neraca keuangan daerah; (g) belum adanya suatu dasar yang jelas dalam melaksanaan pengelolaan aseet milik daerah sehingga menyebabkan instansi yang berwenang ragu untuk melakukan pemanfaatan asset milik daerah; (h) kondisi geografis Kabupaten Kepulauan Sangihe yang memiliki pulau sehingga menyulitkan kegiatan-kegiatan yang berkaitan dengan pengelolaan dan pemanfaatan asset; (i) perubahan-perubahan peraturan yang berdampak para perubahan subjek atas asset antara pemerintah kabupaten dan pemerintah provinsi yang tidak disertai dengan dokumen penyerahan ataupun dokumen yang menjadi dasar perpindahan asset karena adanya perubahan peraturan; dan (j) Peraturan Daerah Kabupaten Sangihe No 9 Tahun 2008 tentang Pengelolaan Barang Milik Daerah sudah tidak memenuhi kriteria adanya pendelasian kewenangan terutama terkait dengan materi muatan dalam pembentukan Peraturan Daerah setelah ditetapkannya Peraturan Pemerintah No 27 Tahun 2014 tentang Pengelolaan Barang Milik Negara/Daerah. Kondisi-kondisi tersebut di atas menyebabkan tidak terlaksanakanya asas pemerintahan yang baik terkait dengan pengelolaan dan pemanfaatan sehingga perlu untuk melakukan kajian mengenai pengelolaan asset pemerintah daerah Kabupaten Kepualauan Sangihe dalam perspektif Good Governance. Berdasarkan uraian yang ada maka permasalahan dalam penelitian ini adalah :

1. Bagaimana peran pengelolaan asset pemerintah kabaputen Kepulauan Sangihe terhadap pembangunan di Kabupaten Kepulauan Sangihe?

2. Bagaimana konstruksi hokum yang ideal pengelolaan asset pemerintah kabaputen Kepulauan Sangihe sehingga dapat mencerminkan penyelenggaraan pemerintahan yang baik? 


\section{METODE}

Penelitian ini diarahkan pada kekhasan ilmu hukum yang sifatnya normatif ${ }^{3,}$ sehingga tipe penelitian ini adalah penelitian hukum normatif, yaitu penelitian yang mengkaji ketentuan hukum positif tertulis secara sistematis terkait dengan pengelolaan asset pemerintah daerah. Di dalam penelitian hukum terdapat beberapa pendekatan. Penelitian hukum dilakukan untuk mencari pemecahan permasalahan atas isu hukum yang timbul. Hasil yang hendak dicapai adalah memberikan preskripsi mengenai apa yang seyogyanya. ${ }^{4}$

Pendekatan yang digunakan adalah pendekatan peraturan perundang-undangan (statute approach) dan pendekatan konseptual (conceptual approach). Sumber bahan hukum terdiri atas bahan hukum primer dan bahan hukum sekunder ${ }^{5}$. Teknik pengumpulan bahan hukum dilakukan melalui prosedur identifikasi serta inventarisasi bahan-bahan hukum primer dan bahan hukum sekunder ${ }^{6}$. Selanjutnya bahan-bahan hukum yang terkumpul tersebut diklasifikasi secara sitematis sesuai dengan rumusan masalah dan tujuan penelitian. Klasifikasi dimaksudkan untuk melakukan pemilahan bahan hukum sesuai dengan analisis yang relevan. Keseluruhan bahan hukum baik primer maupun sekunder yang diperoleh selanjutnya diolah dengan melakukan kategorisasi sebagai pengklasifikasian bahan hukum secara selektif. Keseluruhan bahan hukum dikelompokkan berdasarkan kriteria yang cermat dan ketat sesuai dengan perumusan masalah penelitian untuk dianalisis. Analisis terhadap bahan hukum dilakukan melalui proses penalaran hukum (legal reasoning) yang logis sistematis. Penalaran hukum juga bertumpu pada aturan berfikir yang dikenal dalam logika.

\section{PEMBAHASAN}

\subsection{Peran Pengelolaan Aset Pemerintah Daerah terhadap Pembangunan Daerah}

Pemberlakuan Undang-Undang Otonomi Daerah sejak tahun 1999 memberikan kewenangan yang besar kepada daerah untuk mengatur dan mengurus urusan pemerintahan daerah dalam sistem Negara Kesatuan Republik Indonesia melalui suatu proses yang dikenal dengan desentralisasi. Desentralisasi yang dimaksud dalam hal ini bukan hanya dimaknai sebatas sebagai penyerahan kewenangan secara politik dan administratif tetapi juga penyerahan kewenangan dari sektor fiscal yang disebut sebagai desentralisasi fiskal.

Desentralisasi fiskal merupakan suatu konsep yang dimaksudkan agar daerah memiliki kewenangan untuk menggali sumber pendapatan asli daerahnya sendiri, mengelola keuangan sendiri dan mempergunakannya sesuai dengan perencanaan artinya daerah diberikan kewenangan untuk mengelola daerahnya masing-masing sesuai dengan kebutuhan dan potensi daerahnya. Desentralisasi fiskal juga memberikan kesempatan untuk meningkatkan kesejahteraan ekonomi atau dapat pula dikatakan bahwa melalui desentralisasi diharapkan terjadi peningkatan efisiensi alokasi sumber daya untuk meningkatkan kesejahteraan ekonomi.

Desentralisasi fiskal menuntut daerah agar dapat meningkatkan kreativitas dalam menghimpun pendanaan sehingga dapat membiayai (self financing) pengeluaran daerah sesuai dengan kebutuhannya. Salah satu wujud dari self financing ialah dengan memelihara agar kontribusi pendapatan asli daerah, baik dari sektor pajak daerah, retribusi daerah, dan lainlain pendapatan asli daerah yang sah, menunjukkan tren yang terus meningkat terhadap

\footnotetext{
Hlm. 1

${ }^{3}$ Philipus M Hadjon dan Tatiek Sri Djatmiati. 2005. Argumentasi Hukum. Gajah Mada University Press: Yogyakarta.

${ }^{4}$ Peter Mahmud Marzuki. 2009. Penelitian Hukum . Kencana Predana Media Group : Jakarta. Hlm. 89

${ }^{53}$ Ibid. Hlm. 97

5 Ibid. Hlm. 141

${ }^{6}$ M. Hadjon. Philipus, Merancang dan Menulis Penelitian Hukum Normatif (Teori dan Filsafat), Universitas Airlangga : Surabaya . Hlm. 6
} 
Pendapatan Daerah. Upaya yang dilakukan oleh Pemerintah Daerah untuk meningkatkan PADnya banyak menghadapi tantangan Hal ini disebabkan Pendapatan Asli Daerah khususnya pajak daerah dan retribusi daerah cenderung bias ke daerah yang tingkat urbanisasinya tinggi (urban-biased), seperti Pajak Hotel, Pajak Restoran, dan Pajak Kendaraan Bermotor, dan sebagainya. Salah satu strategi dalam peningkatan PAD yang dapat dilakukan oleh Pemerintah Daerah adalah melalui pengelolaan asset untuk mengoptimalkan aset dan meningkatkan kemampuan aset untuk menghasilkan keuntungan melalui beberapa kontribusi sesuai dengan metode pemanfaatan aset.

Aset secara umum menurut Siregar adalah barang (thing) atau sesuatu barang (anything) yang mempunyai nilai ekonomi (economic value), nilai komersial (commercial value) atau nilai tukar (exchange value) yang dimiliki oleh badan usaha, instansi atau individu. ${ }^{7}$ Dari defenisi ini dapat dikatakan bahwa untuk dapat dikategorikan sebagai aset, maka seuatu harus memiliki nilai.Selanjutnya Martani mengemukakan bahwa aset adalah sebagai sumber daya yang dikuasai oleh entitas sebagai akibat dari peristiwa masa lalu dan darimana manfaat ekonomi di masa depan diharapkan akan diperoleh. ${ }^{8}$ Defenisi ini menunjukkan bahwa suatu asset haruslah dapat memberikan manfaat ekonomi di masa depan. Manfaat ekonomi masa depan yang terwujud dalam aset adalah potensi aset tersebut untuk memberikan sumbangan baik langsung maupun tidak langsung, bagi kegiatan operasional pemerintah, berupa aliran pendapatan dan penghematan belanja bagi pemerintah Dalam Peraturan Pemerintah Republik Indonesia Nomor 24 Tahun 2005 tentang Standar Akuntansi Pemerintahan, paragraf 60 huruf, aset didefinisikan sebagai sumber daya ekonomi yang dikuasai dan/atau dimiliki oleh pemerintah sebagai akibat dari peristiwa masa lalu dan dari mana manfaat ekonomi dan/atau sosial dimasa depan diharapkan dapat diperoleh, baik oleh pemerintah maupun masyarakat, serta dapat diukur dalam satuan uang, termasuk sumber daya nonkeuangan yang diperlukan untuk penyediaan jasa bagi masyarakat umum dan sumber-sumber daya yang dipelihara karena alasan sejarah dan budaya.

Bentuk asset ada 2 (dua) yaitu asset berwujud (fixed asset) dan asset tidak berwujud (intangible asset). Karakteristik aset berwujud menurut Kieso et al. ${ }^{9}$ adalah diperoleh untuk digunakan dalam kegiatan dan tidak untuk dijual, bersifat jangka panjang dan biasanya dapat didepresiasi dan memiliki bentuk fisik sedangkan karakteristik asset tidak berwujud adalah dapat diidentifikasi, tidak mempunyai wujud fisik serta tidak dimiliki untuk digunakan dalam menghasilkan atau menyerahkan barang atau jasa, disewakan kepada pihak lainnya, atau untuk tujuan administratif.

Secara umum, barang adalah bagian dari kekayaan yang merupakan satuan tertentu yang dapat dinilai/dihitung/diukur/ditimbang dan dinilai, tidak termasuk uang dan surat berharga. Undang-undang Nomor 1 tahun 2004 mengatur bahwa Barang Milik Negara (BMN) adalah semua barang yang dibeli atau diperoleh atas beban APBN atau berasal dari perolehan lainnya yang sah. Perolehan lainnya yang sah antara lain barang yang berasal dari hibah, barang yang diperoleh berdasarkan ketentuan undang-undang, barang yang diperoleh sebagai pelaksanaan dari perjanjian/ kontrak, dan barang yang diperoleh berdasarkan putusan pengadilan yang telah memperoleh ketentuan hukum tetap. Tidak termasuk dalam pengertian BMN adalah barang-barang yang dikuasai dan atau dimiliki oleh Pemerintah Daerah (sumber dananya berasal dari APBD termasuk yang sumber dananya berasal dari APBN tetapi sudah diserahterimakan kepada Pemda), Badan Usaha Milik Negara/Badan Usaha Milik Daerah yang terdiri dari perusahaan perseroan, dan Perusahaan Umum serta Bank Pemerintah dan Lembaga Keuangan Milik Pemerintah.

\footnotetext{
${ }^{7}$ Doli Siregar D. 2004. Manajemen Aset. Gramedia Pustaka Utama : Jakarta. Hlm.178.

${ }^{8}$ Dwi Martani. 2012. Akuntansi Keuangan Menengah Berbasis PSAK. Salemba Empat : Jakarta

${ }^{9}$ Al,Kieso et. 2007. Pengantar Akuntansi. Salemba Empat : Jakarta
} 
Uraian di atas menunjukkan bahwa Barang Milik Daerah tidak termasuk dalam kategori dan defenisi dari Barang Milik Negara. Defenisi Barang Milik Daerah menurut Chabib Saleh dan Heru Rochmansjah ${ }^{10}$ adalah semua kekayaan daerah baik yang dibeli atau diperoleh atas beban APBD maupun berasal dari perolehan yang sah yang bergerak maupun tidak bergerak beserta bagian-bagiannya ataupun yang merupakan satuan tertentu yang dapat dinilai, dihitung, diukur, atau ditimbang termasuk hewan dan tumbuh-tumbuhan kecuali uang dan surat berharga lainnya.

Aset daerah juga merupakan semua kekayaan daerah yang dimiliki maupun yang dikuasai pemerintah daerah, yang dibeli atau diperoleh atas beban APBD atau berasal dari perolehan lainnya yanjg sah, misalnya sumbangan, hadiah, donasi, waqaf, hibah, swadaya, kewajiban pihak ketiga, dan sebagainya. Secara umum aset daerah dapat dikategorikan menjadi dua bentuk, yaitu aset keuangan dan aset nonkeuangan. Aset keuangan meliputi kas dan setara kas, piutang, serta surat berharga baik berupa investasi jangka pendek maupun jangka panjang. Aset nonkeuangan meliputi aset tetap, aset lainnya, dan persediaan. ${ }^{11}$

Sementara itu jika dilihat dari penggunaanya, aset daerah dapat dikategorikan menjadi tiga, yaitu : 1) aset daerah yang digunakan untuk operasi pemerintah daerah (local government used assets), 2) aset daerah yang digunakan masyarakat dalam rangka pelayanan publik (social used assets), dan 3) aset daerah yang tidak digunakan untuk permerintah maupun publik (surplus property). Aset daerah jenis ketiga tersebut pada dasarnya merupakan aset yang menganggur dan perlu dioptimalkan pemanfaatannya.

Pengelolaan barang milik daerah dilaksanakan berdasarkan asas fungsional, kepastian hukum, transparansi, efisiensi, akuntabilitas, dan kepastian nilai. Pengelolaan barang milik negara/daerah meliputi: ${ }^{13}$

a. Perencanaan kebutuhan adalah kegiatan merumuskan rincian kebutuhan barang milik negara/daerah untuk menghubungkan pengadaan barang yang telah lalu dengan keadaan yang sedang berjalan sebagai dasar dalam melakukan tindakan yang akan datang.

b. Pengadaan merupakan rangkaian kegiatan yang dilakukan untuk memiliki barang milik negara/daerah melalui suatu rangkaian proses baik melalui jual beli, maupun lelang.

c. Penggunaan adalah kegiatan yang dilakukan oleh pengguna barang dalam mengelola dan menatausahakan barang milik negara/daerah yang sesuai dengan tugas dan fungsi instansi yang bersangkutan.

d. Pemanfaatan adalah pendayagunaan barang milik negara/daerah yang tidak digunakan untuk penyelenggaraan tugas dan fungsi kementerian/ lembaga/satuan kerja perangkat daerah dan/atau optimalisasi barang milik negara/daerah dengan tidak mengubah status kepemilikan.

e. Pengamanan dan pemeliharaan merupakan rangkaian kegiatan yang dilakukan pengelola barang, pengguna barang dan kuasa pengguna barang untuk mengamankan dan memelihara barang milik negara/daerah.

f. Penilaian adalah proses kegiatan untuk memberikan suatu opini nilai atas suatu objek penilaian berupa barang milik negara/daerah pada saat tertentu.

g. Pemindahtanganan adalah pengalihan kepemilikan barang milik negara/daerah.

Dalam ruang lingkup barang milik daerah pemegang kekuasaan pengelolaan barang milik daerah adalah gubernur, bupati, atau walikota dimana pemegang kekuasaan pengelolaan barang milik daerah berwenang dan bertanggung jawab untuk: ${ }^{14}$

\footnotetext{
${ }^{10}$ Chabib Soleh dan Heru Rochmansjah.2014. Pengelolaan Keuangan Desa. Fokus Media : Bandung

${ }^{11}$ Mahmudi. 2010. Manajemen Keuangan Daerah 'seri: pemberdayaan akuntabilitas publik'. Erlangga : Jakarta. Hlm. 146.

${ }^{12}$ ibid

${ }^{13}$ Peraturan Pemerintah Nomor 27 Tahun 2014 Tentang Pengelolaan Barang Milik Negara/Daerah
} 
a. Menetapkan kebijakan pengelolaan barang milik daerah.

b. Menetapkan penggunaan, pemanfaatan, atau pemindahtanganan barang milik daerah berupa tanah dan/atau bangunan.

c. Menetapkan kebijakan pengamanan dan pemeliharaan barang milik daerah.

d. Menetapkan pejabat yang mengurus dan menyimpan barang milik daerah.

e. Mengajukan usul pemindahtanganan barang milik daerah yang memerlukan persetujuan dewan perwakilan rakyat daerah.

f. Menyetujui usul pemindahtanganan, pemusnahan, dan penghapusan barang milik daerah sesuai batas kewenangannya.

g. Menyetujui usul pemanfaatan barang milik daerah berupa sebagian tanah dan/atau bangunan dan selain tanah dan/atau bangunan, dan

h. Menyetujui usul pemanfaatan barang milik daerah dalam bentuk kerja sama penyediaan infrastruktur.

Pengelola barang milik daerah dilaksanakan oleh sekretaris daerah. Sekretaris daerah selaku pengelola barang milik daerah berwenang dan bertanggung jawab untuk: ${ }^{15}$

a. Meneliti dan menyetujui rencana kebutuhan barang milik daerah.

b. Meneliti dan menyetujui rencana kebutuhan pemeliharaan/perawatan barang milik daerah.

c. Mengajukan usul pemanfaatan dan pemindahtanganan barang milik daerah yang memerlukan persetujuan gubernur/bupati/walikota.

d. Mengatur pelaksanaan penggunaan, pemanfaatan, pemusnahan, dan penghapusan barang milik daerah.

e. Mengatur pelaksanaan pemindahtanganan barang milik daerah yang telah disetujui oleh gubernur/ bupati/walikota atau dewan perwakilan rakyat daerah.

f. Melakukan koordinasi dalam pelaksanaan inventarisasi barang milik daerah, dan

g. Melakukan pengawasan dan pengendalian atas pengelolaan barang milik daerah.

Pengguna barang milik daerah adalah kepala satuan kerja perangkat daerah (SKPD), dimana pengguna barang milik daerah berwenang dan bertanggung jawab untuk:

a. Mengajukan rencana kebutuhan dan penganggaran barang milik daerah bagi satuan kerja perangkat daerah yang dipimpinnya.

b. Mengajukan permohonan penetapan status penggunaan barang milik daerah yang diperoleh dari beban anggaran pendapatan dan belanja daerah dan perolehan lainnya yang sah.

c. Melakukan pencatatan dan inventarisasi barang milik daerah yang berada dalam penguasaannya.

d. Menggunakan barang milik daerah yang berada dalam penguasaannya untuk kepentingan penyelenggaraan tugas dan fungsi satuan kerja perangkat daerah yang dipimpinnya.

e. Mengamankan dan memelihara barang milik daerah yang berada dalam penguasaannya.

f. Mengajukan usul pemanfaatan dan pemindahtanganan barang milik daerah berupa tanah dan/atau bangunan yang tidak memerlukan persetujuan dewan perwakilan rakyat daerah dan barang milik daerah selain tanah dan/atau bangunan.

g. Menyerahkan barang milik daerah berupa tanah dan/atau bangunan yang tidak digunakan untuk kepentingan penyelenggaraan tugas dan fungsi satuan kerja perangkat daerah yang dipimpinnya dan sedang tidak dimanfaatkan pihak lain, kepada gubernur/ bupati/walikota melalui pengelola barang.

\footnotetext{
${ }^{14}$ Pasal 5 Ayat (2) Peraturan Pemerintah Nomor 27 Tahun 2014 Tentang Pengelolaan Barang Milik Negara/Daerah

${ }^{15}$ Pasal 5 Ayat (4) Peraturan Pemerintah Nomor 27 Tahun 2014 Tentang Pengelolaan Barang Milik Negara/Daerah
} 
h. Mengajukan usul pemusnahan dan penghapusan barang milik daerah.

i. Melakukan pembinaan, pengawasan, dan pengendalian atas penggunaan barang milik daerah yang berada dalam penguasaannya, dan

j. Menyusun dan menyampaikan laporan barang pengguna semesteran dan laporan barang pengguna tahunan yang berada dalam penguasaannya kepada pengelola barang.

Aset daerah membutuhkan pengelolaan. Pengelolaan memiliki padanan kata manajemen, yang diserap dari bahasa Inggris to-manage yang secara leksikal diartikan "mengurus, mengatur,melaksanakan,mengelola", atau "proses penggunaan sumberdaya secara efektif untuk mencapai sasaran". ${ }^{17}$ Dari segi istilah ditemukan banyak definisi tentang manajemen. Definisi yang sering digunakan adalah dari Ricky W.Griffin, dimana manajemen dijelaskan sebagai proses perencanaan, pengorganisasian, pengkordinasian dan pengendalian atau kontrol sumber daya dalam mencapai sasaran dengan efisien dan efektif. ${ }^{18}$ Pengelolaan asset daerah pada dasarnya berhubungan dengan manajemen materi dan manajemen perlengkapan daerah. Manajemen materi menurut Sedarmayanti adalah proses kegiatan perencanaan kebutuhan pemilihan sumber, pembelian, pemindahan,penyimpanan, dan pengawasan materil/produksi dalam rangka meningkatkan keuntungan perusahaan. ${ }^{19}$ Mardiasmo mengemukakan bahwa terdapat tiga prinsip dasar pengelolaan kekayaan asset daerah yaitu : ${ }^{20}$

a. Adanya perencanaan yang tepat.

b. Pelaksanaan pemanfaatan secara efektif dan efisien.

c. Pengawasan (monitoring).

Siregar ${ }^{21}$ menyebutkan bahwa tujuan manajemen aset secara umum adalah :

a. Mengidentifikasi dan inventarisasi semua aset meliputi bentuk, ukuran, fisik, legal, sekaligus mengetahui nilai pasar atas masing-masing aset tersebut yang mencerminkan manfaat ekonomisnya.

b. Mengoptimalkan pemanfaatan aset, apakah aset tersebut telah sesuai dengan peruntukkannya atau tidak.

c. Terciptanya suatu sistem informasi dan administrasi sehingga tercapainya efisien dan efektif dalam pengelolaan asset.

Sugiama ${ }^{22}$ memerinci proses manajemen aset sebagai siklus kegiatan mulai dari merencanakan kebutuhan aset, mendapatkan, menginventarisasi, melakukan legal audit, menilai, mengoperasikan, memelihara, membaharukan atau menghapuskan hingga mengalihkan aset melalui penjualan, penghibahan, penyertaan modal atau pemusnahan.Siregar ${ }^{23}$ manajemen aset pemerintah daerah dapat dibagi dalam lima tahap kerja yang meliputi; inventarisasi aset, legal audit, penilaian aset, optimalisasi pemanfaatan dan pengembangan SIMA (sistem informasi manajemen aset), di mana kelima tahapan tersebut adalah saling berhubungan dan terintegrasi satu dengan yang lainnya. Otonomi Daerah, peran dan tugas Pemerintah Daerah terhadap Pembangunan dan Pelayanan Kebutuhan publik semakin besar. Oleh sebab itu dituntut untuk memaksimalkan manfaat dari sumber daya barang milik daerah agar tujuan penyelenggaraan pemerintahan daerah tercapai.

${ }^{16}$ John M. Echols dan Hasan Shadily. Kamus Inggeris Indonesia.Gramedia : Jakarta. Hlm. 372.

${ }^{17}$ Depdikbud. 1999. Kamus Besar Bahasa Indonesia. Balai Pustaka : Jakarta.

${ }^{18}$ Ricky W Griffin. 2002. Manajemen (terj).. Erlangga: Jakarta. Hlm.5.

${ }^{19}$ Soedarmayanti. 2000. Restrukturisasi dan Pemberdayaan Organisasi untuk Menghadapi Dinamika Perubahan Lingkungan

${ }^{20}$ Mardiasmo. 2002. Prinsip-Prinsip Manajemen Dalam Pembiayaan Desentralisasi. Yogyakarta: FEUGM, h.35

${ }^{21}$ 1Doli Siregar D. 2004. Manajemen Aset. Gramedia Pustaka Utama: Jakarta. Hlm.178

${ }^{22}$ A. Gima Sugiama. 2013. Manajemen Aset Pariwisata. Guardaya Intimarta : Bandung. Hlm.15.

${ }^{23}$ Doli Siregar. Op cit. 


\subsection{Konstruksi Hukum yang Ideal Pengelolaan Aset Pemerintah Daerah yang} Mencerminkan Asas Pemerintahan yang Baik

Dalam rangka memberikan pelayanan yang efisien ${ }^{24}$ dan efektif ${ }^{25}$ kepada masyarakat, maka pemerintah daerah diberikan kewenangan secara penuh untuk mengurus rumah tangganya sendiri dan dituntut pula menggali dan mengelola sumber-sumber pendapatan asli daerah secara optimal berdasarkan peraturan perundang-undangan yang berlaku. Pemerintah daerah harus kreatif untuk mengembangkan dan meningkatkan kemampuannya baik dari segi sumber daya manusia maupun sistem dan prosedur yang digunakan dalam menunjang kesejahteraan rakyat di daerah. Hal ini kemudian memberikan peluang kepada pemerintah daerah untuk dapat menerapkan kebijakan-kebijakan yang dianggap perlu demi kesejahteraan rakyat di daerah masing-masing. Keadaan ini kemudian mendorong pemerintah daerah untuk mengambil dan memberlakukan kebijakan-kebijakan yang bersifat mengatur keadaan di daerah dengan mengeluarkan berbagai macam perundangundangan antara lain Peraturan Daerah (Perda).

Ridwan H.R. ${ }^{26}$ mengemukakan bahwa dalam kajian teoritis instrumen-instrumen penyelenggaraan pemerintahan dikenal dua aspek yaitu pertama, instrumen dalam bentuk sarana dan prasarana yang digunakan dalam menjalankan tugas dan fungsinya dalam pemerintahan yang digolongkan ke dalam public domain. Kedua, instrumen hukum (yuridis) yaitu sejumlah peraturan perundang-undangan, keputusan-keputusan, peraturan kebijaksanaan, perizinan dan sebagainya. Hal ini menunjukkan bahwa Perda merupakan instrumen hukum (yuridis) penyelenggaraan pemerintahan daerah sehingga diperlukan suatu pengaturan Perda yang baik sehingga mampu merefleksikan suatu tatanan hukum responsif maupun yang mampu memberikan ruang bagi terwujudnya suatu tata pemerintahan yang baik.

Undang-undang No. 12 Tahun 2011 merupakan landasan yuridis pembentukan peraturan perundang-undangan baik di tingkat pusat maupun daerah. Undang-undang ini memuat pengaturan tentang sistem, asas, jenis, dan materi muatan, proses pembentukan yang dimulai dari perencanaan, persiapan, teknik penyusunan, perumusan, pembahasan, pengesahan, pengundangan, dan penyebarluasan. Tertib pembentukan peraturan perundangundangan baik di tingkat pusat maupun daerah diatur sesuai dengan proses pembentukan dari jenis dan hirarki serta materi muatan peraturan perundang-undangan. Sejak berlakunya UUD 1945 eksistensi Perda telah diakui sebagai salah satu jenis peraturan perundangundangan yang berlaku dan mengikat umum bahkan Perda selalu diakui keberadaannya di dalam sistem hukum di Indonesia. Perda merupakan salah satu jenis peraturan perundang-

${ }^{24}$ Peter Drucker dalam Kisdarto. 2002. Menuju Sumber Daya Manusia Berdaya. Prestasi Pustaka Publisher : Jakarta, halaman 139 mengemukakan bahwa efficiency is to do the things right (efisiensi adalah melakukan hal secara benar). Sedangkan Chester Barnard dalam ibid mengemukakan bahwa the efficiency of a cooperative system is the resultant of the efficiency of the individuals furnishing the constituent effort, that is, as viewed by them (efisiensi dari suatu kerjasama dalam suatu sistem (antar individu) adalah hasil gabungan efisiensi dari upaya yang dipilih masing-masing individu)

25 Peter Drucker mengemukakan bahwa bahwa effectiveness is to do the right things (efektivitas adalah melakukan hal yag benar ). Sedangkan Chester Barnard dalam ibid mengemukakan bahwa effectiveness of cooperative effort relates to accomplishment of an objective of the system and it is determined with a view to the system's requirement. (Efektivitas dari usaha kerjasama (antar individu) berhubungan dengan pelaksanaan yang dapat mencapai suatu tujuan dalam suatu sistem, dan hal itu ditentukan dengan suatu pandangan dapat memenuhi kebutuhan sistem itu sendiri).

${ }^{26}$ Ridwan, HR. 2006. Hukum Administrasi Negara.UII Press: Yogyakarta. Halaman 100. 
undangan yang dibentuk oleh pemerintah tingkat daerah dalam rangka penyelenggaraan otonomi daerah. ${ }^{27}$

Perda merupakan penjabaran lebih lanjut dari peraturan perundang-undangan yang lebih tinggi dengan memperhatikan ciri khas masing-masing daerah. Perda dilarang bertentangan dengan kepentingan umum dan/atau peraturan perundang-undangan yang lebih tinggi. Salah satu peraturan perundang-undangan yang harus menjadi acuan perda adalah Peraturan Pemerintah sehingga penggantian peraturan pemerintah haruslah diikuti oleh peraturan daerah untuk menjaga harmonisasi peraturan perundang-undangan. Dalam pengelolaan barang milik negara/daerah pemerintah melakukan beberapa penyempurnaan atas peraturan sebelumnya dalam PP No. 6 Tahun 2006 melalui pembentukan PP No. 27 Tahun 2014. Pokok-pokok penyempurnaan tersebut adalah: (1) Penyempurnaan Siklus Pengelolaan BMN/D; (2) Harmonisasi dengan peraturan perundang-undangan lain; (3) Penguatan dasar hukum pengaturan; (4) Penyederhanaan birokrasi; (5) Pengembangan manajemen aset negara; dan (6) Penyelesaian kasus yang telah terlanjur terjadi.

Dengan perubahan tersebut, diharapkan PP Nomor 27 Tahun 2014 mampu mengakomodir dinamika pengelolaan $\mathrm{BMN} / \mathrm{D}$, meminimalisir multitafsir atas pengelolaan BMN/D, mempertegas hak, kewajiban, tanggung jawab, kewenangan pengguna dan pengelola dan harmonisasi dengan peraturan terkait.Dalam PP No. 27 Tahun 2014, terdapat beberapa perbedaan dengan PP No. 6 Tahun 2006 sebagai berikut : ${ }^{28}$

1. Terdapat tambahan penjelasan mengenai definisi Kerja Sama Penyediaan Infrastruktur yang dilakukan karena adalam PP 27 Tahun 2014 ditambahkan satu mekanisme pemanfaatan BMN/D yaitu Kerja Sama Penyediaan Infrastruktur sehingga diperlukan definisi yang jelas untuk menghindari perbedaan persepsi.

2. Terdapat tambahan penjelasan menganai definisi Pemusnahan. Hal ini dilakukan mengingat pada PP 27 Tahun 2014 ditambahkan satu tahapan dalam siklus pengelolaan BMN/D sehingga diperlukan definisi yang jelas untuk menghindari perbedaan persepsi.

3. Terdapat tambahan penjelasan mengenai definisi Daftar Barang Pengguna dan Daftar Barang Kuasa Pengguna. Dengan mencantumkan definisi kedua istilah tersebut dapat mencegah kebingungan bagi pembaca mengingat penggunaan istilah Daftar Barang Pengguna dan Daftar Barang Kuasa Pengguna banyak digunakan dalam PP 27 Tahun 2014 ini.

4. Terdapat perubahan pada beberapa definisi, yaitu pada istilah Penilai, Penilaian, Pemanfaatan, dan Pemindahtanganan. Perubahan ini menyesuaikan dengan dinamika pengelolaan BMN/D dan menghindari ketidasinkronan dengan peraturan lain.

5. Definisi Kementerian Negara/Lembaga dipecah menjadi satu definisi tersendiri untuk Kementerian Negara dan definisi yang lain untuk Lembaga. Hal ini wajar dilakukan mengingat definisi Kementerian Negara/Lembaga pada PP 6 Tahun 2006 tidak jelas dan dapat menimbulkan multitafsir.

6. Ketentuan mengenai pemusnahan dijadikan bab tersendiri dalam PP 27 Tahun 2014 sebagaimana ketentuan mengenai pemindahtanganan.

7. Pemindahtanganan dan Pemusnahan terletak setelah Bab Penghapusan. Perubahan ini dilakukan mengingat proses penghapusan idealnya terjadi setelah adanya pemusnahan atau pemindahtanganan.

8. Terdapat perubahan wewenang pengelola BMN/D yang semula memberi keputusan menjadi memberi persetujuan atas usulan pemindahtanganan; pemanfaatan; serta

\footnotetext{
${ }^{27}$ Donna Okthalia Setiabudi. 2010. hakikat Peraturan Daerah dalam rangka tata kelola peraturan perundangundangan yang baik. Disertasi.Universitas Hasanuddin. Hlm. 5

28 Amela Erliana Crhistine. Perbandingan PP 27 Tahun 2014 Tentang Pengelolaan Barang Milik Negara/Daerah dengan PP 6 Tahun 2006 dan PP 38 Tahun 2008. STAN. Hlm. 7
} 
pemusnahan dan penghapusan BMN/D. Hal ini dilakukan untuk menyederhanakan birokrasi dan pengguna/kuasa pengguna barang lebih mengetahui mengenai kondisi BMN/D yang berada di dalam wewenangnya.

9. PP 27 Tahun 2014 membolehkan Pengelola Barang untuk mendelegasikan kewenangan dan tanggung jawab tertentu kepada Pengguna Barang/Kuasa Pengguna Barang. Jenis kewenangan dan tanggung jawab yang dapat didelegasikan dan tata cara pendelegasiannya diatur lebih lanjut dalam PMK atau peraturan perundang-undangan mengenai BMN/D.

10. Terdapat tambahan kewenangan dan tanggung jawab Gubernur/Bupati/Walikota selaku pemegang kekuasaan pengelolaan BMD, yaitu Menetapkan pejabat yang mengurus dan menyimpan BMD. Kewenangan ini semula dimiliki Sekretaris Daerah sebagai pengelola BMD.

11. Terdapat tambahan kewenangan dan tanggung jawab Kepala Daerah, yaitu menyetujui usul Pemanfaatan BMD dalam bentuk Kerja Sama Penyediaan Infrastruktur.

12. Terdapat tambahan kewenangan dan tanggung jawab Pengguna BMN/D, yaitu mengajukan usul Pemanfaatan BMN/D serta usul Pemusnahan dan Penghapusan BMN/D kepada Pengelola Barang. Tidak lagi dibedakan antara tanah dan bangunan dengan selain tanah dan bangunan untuk beberapa poin pasal sebagaimana pada PP 6 Tahun 2006. Perubahan ini menyempurnakan aturan mengenai wewenang dan tanggung jawab Pengguna BMN/D. Selain itu, dengan tidak dibedakannya BMN/D tanah bangunan dengan selain tanah bangunan memberi keleluasaan pada pengguna barang dalam mengelola BMN/D.

13. PP 27 Tahun 2014 membolehkan Pengguna Barang untuk mendelegasikan kewenangan dan tanggung jawab tertentu kepada Kuasa Pengguna Barang. Jenis kewenangan dan tanggung jawab yang dapat didelegasikan dan tata cara pendelegasiannya diatur peraturan perundang-undangan mengenai BMN. Ketentuan ini menguatkan dasar hukum mengenai pendelegasian wewenang dan tanggung jawab yang dimiliki Pengguna Barang. Hal ini merupakan salah satu langkah untuk menyederhanakan birokrasi dan mencapai efisiensi pengelolaan BMN/D, tapi tentu saja diperlukan peraturan turunan yang mengatur masalah ini secara lebih rinci.

14. Dalam PP 27 Tahun 2014, Perencanaan Kebutuhan Barang Milik Negara/Daerah disusun dengan memperhatikan kebutuhan pelaksanaan tugas dan fungsi Kementerian/Lembaga/satuan kerja perangkat daerah serta ketersediaan Barang Milik Negara/Daerah yang ada. Perubahan ini dilakukan untuk mempertegas bahwa perencanaan kebutuhan dan penganggaran BMN/D haruslah memperhatikan kebutuhan pelaksanaan tugas dan fungsi penyelenggaraan pemeritahan. Apabila perubahan ini tidak dibuat dan perencanaan disusun hanya dengan memperhatikan ketersediaan sebagaimana diatur dalam PP 6 Tahun 2006 maka dapat timbul multitafsir yang dapat memicu ketidakefektifan dan ketidakefisienan pengelolaan BMN/D.

15. PP 27 Tahun 2014 merinci ruang lingkup perencanaan kebutuhan yaitu meliputi perencanaan pengadaan, pemeliharaan, pemanfaatan, pemindahtanganan, dan penghapusan BMN/D. Hal ini juga dilakukan untuk mencegah penafsiran perencanaan kebutuhan BMN/D hanya sebatas perencanaan pengadaan. Ketentuan ini sesuai dengan prinsip manajemen aset, perencanaan aset harus mencakup perencanaan atas seluruh siklus hidup aset.

16. Terdapat penegasan bahwa Penetapan standar kebutuhan oleh Gubernur/Bupati/ Walikota harus dilakukan berdasarkan pedoman yang ditetapkan Menteri Dalam Negeri dan Standar harga harus ditetapkan sesuai dengan ketentuan peraturan perundang-undangan. Penegasan ini dilakukan untuk menyamakan persepsi bahwa penetapan standar kebutuhan dan standar harga haruslah sesuai dengan ketentuan perundang-undangan yang ada. 
17. Pada PP 6 Tahun 2006, penetapan status penggunaan barang berlaku untuk seluruh BMN/D. Hal ini kemudian disederhanakan di PP 27 Tahun 2014 di mana terdapat pengecualian Penetapan Status Penggunaan yang tidak dilakukan terhadap BMN/D berupa: barang persediaan; konstruksi dalam pengerjaan; atau barang yang dari awal pengadaannya direncanakan untuk dihibahkan, BMN yang berasal dari dana dekonsentrasi dan dana penunjang tugas pembantuan, yang direncanakan untuk diserahkan, BMN lainnya yang ditetapkan lebih lanjut oleh Pengelola Barang atau BMD lainnya yang ditetapkan lebih lanjut oleh Gubernur/Bupati/Walikota. Hal ini bertujuan untuk menyederhanakan proses birokrasi.

18. PP 27 Tahun 2014 menyederhanakan proses penetapan status penggunaan BMN/D sebagai berikut: (a) Pengelola Barang dapat mendelegasikan penetapan status Penggunaan BMN selain tanah/bangunan kepada Pengguna Barang/Kuasa Pengguna Barang; (b) Gubernur/Bupati/Walikota dapat mendelegasikan penetapan status Penggunaan atas Barang Milik Daerah selain tanah dan/atau bangunan dengan kondisi tertentu kepada Pengelola Barang Milik Daerah; dan (c) Dalam kondisi tertentu, Pengelola Barang dapat menetapkan status Penggunaan Barang Milik Negara pada Pengguna Barang tanpa didahului usulan dari Pengguna Barang Penyederhanaan ini dapat memangkas rantai birokrasi yang panjang saat pengelola barang menghadapi kondisi tertentu yang menuntut kesigapan.

19. Terdapat penambahan ketentuan mengenai pengalihan BMN/D di mana BMN/D dapat dialihkan status penggunaannya dari Pengguna Barang kepada Pengguna Barang lainnya untuk penyelenggaraan tugas dan fungsi berdasarkan persetujuan Pengelola Barang. Selain itu juga disebutkan bahwa BMN/D yang telah ditetapkan status penggunaannya pada Pengguna Barang dapat digunakan sementara oleh Pengguna Barang lainnya dalam jangka waktu tertentu tanpa harus 18 mengubah status Penggunaan BMN/D tersebut setelah terlebih dahulu mendapatkan persetujuan Pengelola Barang/Gubernur/ Bupati/Walikota.

20. Terdapat pengecualian kewajiban penyerahan BMN/D berupa tanah atau bangunan yang tidak digunakan apabila BMN/D tersebut telah direncanakan untuk digunakan atau dimanfaatkan dalam jangka waktu tertentu yang ditetapkan oleh Pengguna Barang, untuk BMN, atau Gubernur/Bupati/Walikota, untuk BMD.

21. Terdapat tambahan sanksi bagi pengguna barang yang tidak menyerahkan BMN/D yang tidak digunakan, yaitu penundaan penyelesaian atas usulan Pemanfaatan, Pemindahtanganan, atau Penghapusan BMN/D.

22. Terdapat bentuk pemanfaatan baru, yaitu: "Kerja Sama Penyediaan Infrastruktur" yang masa sewanya dapat lebih dari 5 (lima) tahun dan dapat diperpanjang. Hal ini telah sesuai dengan dinamika pengelolaan BMN/D saat ini.

23. Terdapat penambahan aturan mengenai jangka waktu penyewaan untuk sewa infrastuktur.

24. Terdapat batasan waktu penyetoran uang sewa yang harus dilakukan sekaligus secara tunai paling lambat 2 (dua) hari kerja sebelum ditandatanganinya perjanjian sewa. Ketentuan penyetoran uang sewa yang harus dilakukan sekaligus dapat dipahami mengingat hal ini akan mempermudah proses pengawasan dan audit.

25. Terdapat perubahan jangka waktu pinjam pakai dari 2 tahun menjadi 5 tahun dan hanya bisa diperpanjang 1 kali. Dengan pembatasan tersebut, pemanfaatan BMN/D secara 20 pinjam pakai hanya bisa dilakukan maksimal selama 10 tahun.

26. Terdapat tambahan mengenai kerja sama pemanfaatan berupa penyediaan infrastruktur. Hal ini telah sesuai dengan dinamika pengelolaan BMN/D mengingat pelaksanaan kerja sama pemanfaatan telah berkembang ke BMN/D berupa infrastruktur. 
27. Batas minimal peserta tender, yang semula pada PP 6 tahun 2006 dinyatakan sekurangkurangnya lima peserta, dihilangkan.

28. Dalam jangka waktu pengoperasian, hasil Bangun Guna Serah /Bangun Serah Guna harus digunakan langsung untuk penyelenggaraan fungsi Pemerintah Pusat/Daerah paling sedikit $10 \%$.

29. Ditegaskan bahwa semua biaya persiapan Bangun Guna Serah /Bangun Serah Guna yang terjadi setelah ditetapkannya mitra Bangun Guna Serah /Bangun Serah Guna dan biaya pelaksanaan Bangun Guna Serah /Bangun Serah Guna menjadi beban mitra Bangun Guna Serah /Bangun Serah Guna. Selain untuk mempertegas hak dan kewajiban mitra Bangun Guna Serah /Bangun Serah Guna, perubahan ini dilakukan untuk memperjelas siapa yang wajib menanggung biaya persiapan dan pelaksanaan Bangun Guna Serah /Bangun Serah Guna.

30. Terdapat penegasan bahwa hasil Bangun Serah Guna yang diserahkan kepada Pengelola Barang ditetapkan sebagai BMN/D. Hal ini untuk memperjelas status dan menghindari kesalahan penafsiran mengenai hasil BSG yang diserahkan kepada pengelola barang.

31. Terdapat penambahan pasal yang berbunyi "Pengelola Barang dapat menetapkan kebijakan asuransi dalam rangka pengamanan BMN tertentu dengan mempertimbangkan kemampuan keuangan negara". Pasal ini menjadi dasar hukum atas implementasi asuransi dalam pengelolaan BMN/D. Hal ini sangat penting mengingat asuransi merupakan salah satu alternatif dalam mitigasi risiko dan telah sangat umum dalam penggunaannya dalam kebijakan manajemen aset.

32. Terdapat penegasan bahwa biaya pemeliharaan BMN/D yang pemanfaatannya dilakukan oleh Pihak Lain ditanggung oleh pihak tersebut. Ketentuan ini sudah selayaknya ditambahkan untuk menegaskan hak dan kewajiban pihak ketiga yang memanfaatkan BMN/D serta menghindari kemungkinan kerugian negara akibat kelalaian dalam perjanjian pemanfaatan BMN/D.

33. Terdapat beberapa perubahan teknis terkait istilah jenis penilai dan tujuan penilaian. Hal ini dilakukan untuk mencapai kesamaan persepsi mengenai penilaian BMN/D serta harmonisasi dengan peraturan lainnya.

34. Terdapat ketentuan mengenai penilaian kembali dalam kondisi tertentu yang dapat dilakukan pengelola barang atas nilai BMN/D yang telah ditetapkan dalam neraca Pemerintah Pusat/Daerah keputusan mengenai Penilaian kembali atas nilai BMN dilaksanakan berdasarkan ketentuan Pemerintah yang berlaku secara nasional. Perubahan ini dilakukan dalam rangka sinkronisasi kebijakan dengan Standar Akuntansi Pemerintah berbasis akrual.

35. Terdapat penyederhanaan birokrasi dalam hal subjek pelaksana penjualan BMN/D. Pemisahan subjek tidak lagi berdasarkan jenis BMN/D (tanah dan bangunan atau bukan), tapi berdasarkan lingkup penguasaan barang. Menurut penulis pengelompokan ini lebih tepat serta lebih efisien dalam pelaksanaannya.

36. Terdapat dasar perhitungan nilai limit penjualan BMN secara lelang yaitu dengan memperhitungkan faktor penyesuaian. PP 6 Tahun 2006 tidak mengatur hal tersebut.

37. Terdapat perluasan mitra tukar-menukar dengan diizinkannya melakukan tukar-menukar dengan pemerintah negara lain. Dengan cakupan yang lebih luas ini diharapkan pemindahtangan dalam bentuk tukar-menukar dapat lebih fleksibel.

38. Terdapat perluasan pertimbangan hibah yang semula hanya mempertimbangkan kepentingan sosial, keagamaan, kemanusiaan, dan penyelenggaraan pemerintahan negara/daerah, kini ditambahkan pertimbangan kepentingan budaya, dan pendidikan yang bersifat non komersial. Dengan perubahan ini diharapkan cakupan hibah BMN akan lebih luas dan bermanfaat bagi masyarakat. 
39. Sebelumnya pada PP 6 Tahun 2006, aturan mengenai pemusnahan digabungkan dalam aturan mengenai penghapusan. Hal ini kurang tepat mengingat penghapusan BMN/D tidak semata-mata akibat adanya pemusnahan.

40. Terdapat penjelasan mengenai cara-cara pemusnahan BMN/D, yaitu dengan cara dibakar, dihancurkan, ditimbun, ditenggelamkan atau cara lain sesuai dengan ketentuan Peraturan Perundang-undangan. Hal ini sangat penting untuk mencapai kesamaan persepsi tentang tindakan apa saja yang termasuk dalam kriteria pemusnahan.

41. Terdapat beberapa perubahan terkait lingkup penerbitan SK Penghapusan dan dasar penghapusan BMN/D. Perubahan ini dilakukan untuk menyederhanakan rantai birokrasi agar tidak kaku dan lebih efisien kesimpulan dan saran secara garis besar penulis menyetujui perubahan yang ada dalam bab ini.

42. Terdapat perubahan dalam ketentuan pembukuan BMN/D yaitu adanya penjelasan lebih rinci alur penyusunan Daftar Barang Milik Negara/Daerah yang sebelumnya tidak dijelaskan dalam PP 6 tahun 2006. Dengan perubahan ini diharapkan tidak ada lagi kebingungan ataupun perbedaan persepsi atas mekanisme pembukuan BMN/D.

43. Perubahan Pada Ketentuan Pembinaan, Pengawasan, dan Pengendalian Analisis Terdapat tambahan ketentuan penetapan indikator kinerja di bidang pengelolaan Barang Milik Negara pada unit yang membidangi pengelolaan Barang Milik Negara oleh Pengguna Barang sebagai salah satu proses pengawasan dan pengendalian. Perubahan ini merupakan bentuk harmonisasi dengan kebijakan terkait penilaian kinerja.

44. Ketentuan Mengenai Pengelolaan BMN oleh Badan Layanan Umum Analisis Pada PP 6 Tahun 2006 tidak ada bagian khusus yang mengatur mengenai pengelolaan BMN/D oleh BLU. Ketentuan ini ditambahkan untuk memberi penegasan mengenai mekanisme pengelolaan BMN/D pada BLU sekaligus sebagai bentuk harmonisasi dengan kebijakan terkait BLU.

45. Ketentuan Mengenai BMN/D Berupa Rumah Negara Analisis Ketentuan mengenai BMN/D berupa rumah negara sebelumnya tidak diatur dalam PP 6 Tahun 2006. Hal ini menimbulkan ketidaksinkronan dengan aturan mengenai rumah negara. Rumah negara itu sendiri merupakan bagian BMN/D akan tetapi mendapatkan perlakuan yang berbeda dari BMN/D pada umumnya.

Perubahan-perubahan dalam substansi hokum pengelolaan barang milik daerah melalui PP NO. 27 Tahun 2014 tentu saja harus diikuti dengan perubahan substansi hokum dalam Peraturan Daerah yang mengatur tentang Pengelolaan Barang Milik Daerah. Pembentukan Rancangan Peraturan Daerah tentang Pengelolaan Barang MIlik Daerah merupakan sarana untuk menjaga agar terlaksananya :

1. terwujudnya batasan dan hubungan yang jelas tentang hak, tanggung jawab, kewajiban, dan kewenangan seluruh pihak yang terkait dengan pengelolaan barang milik daerah;

2. terwujudnya sistem penyelenggaraan Pengelolaan Barang Milik Negara/Daerah mengatur mengenai Perencanaan Kebutuhan dan penganggaran, pengadaan, Penggunaan, Pemanfaatan, pengamanan dan pemeliharaan, Penilaian, Penghapusan, Pemindahtanganan, Penatausahaan, pembinaan, pengawasan dan pengendalian;

3. terwujudnya Perencanaan Barang Milik Daerah merupakan kegiatan yang dilaksanakan untuk menghubungkan antara ketersediaan Barang Milik Daerah sebagai hasil pengadaan yang telah lalu dengan keadaan yang sedang berjalan dalam rangka meningkatkan efisiensi pengelolaan keuangan negara; dan

4. Perencanaan Barang Milik Daerah harus dapat mencerminkan kebutuhan riil Barang Milik Daerah pada satuan kerja perangkat daerah, sehingga dapat dijadikan dasar dalam penyusunan rencana kebutuhan Barang Milik Daerah pada rencana kerja dan anggaran satuan kerja perangkat daerah. 
Pembentukan Peraturan Daerah Kabupaten Kepulauan Sangihe tentang Pengelolaan Barang Milik Daerah membawa implikasi pada aspek keuangan daerah, sehingga sangat diperlukan adanya pengaturan sebagai dasar pengelolaan barang milik daerah .

\section{KESIMPULAN}

a. Peran Barang Milik Daerah dalam pembangunan adalah untuk menghasilkan keuntungan melalui beberapa kontribusi sesuai dengan metode pemanfaatan asset, memaksimalkan manfaat dari sumber daya barang milik daerah agar tujuan penyelenggaraan pemerintahan daerah tercapai.

b. Konstruksi hukum yang ideal pengaturan pengelolaan asset daerah yang mencerminkan asas pemerintahan yang baik adalah substansi hokum yang harmonis dengan Peraturan Pemerintah No. 27 Tahun 2014 dengan tidak mengesampingkan kondisi khusus dari daerah setempat sehingga Peraturan Daerah yang dibentuk adalah peraturan daerah yang memenuhi dua kedudukan yaitu sebagai local legislation dan subordinary legislation.

\section{DAFTAR PUSTAKA}

Al,Kieso et. 2007. Pengantar Akuntansi. Salemba Empat : Jakarta

Amela Erliana Crhistine. Perbandingan PP 27 Tahun 2014 Tentang Pengelolaan Barang Milik Negara/Daerah dengan PP 6 Tahun 2006 dan PP 38 Tahun 2008. STAN. Hlm. 7

A. Gima Sugiama. 2013. Manajemen Aset Pariwisata. Guardaya Intimarta : Bandung.

Chabib Soleh dan Heru Rochmansjah.2014. Pengelolaan Keuangan Desa. Fokus Media : Bandung

Doli Siregar D. 2004. Manajemen Aset. Gramedia Pustaka Utama : Jakarta.

Donna Okthalia Setiabudi. 2010. hakikat Peraturan Daerah dalam rangka tata kelola peraturan perundang-undangan yang baik. Disertasi.Universitas Hasanuddin.

Dwi Martani. 2012. Akuntansi Keuangan Menengah Berbasis PSAK. Salemba Empat : Jakarta

John M. Echols dan Hasan Shadily. Kamus Inggeris Indonesia.Gramedia : Jakarta.

Mahmudi. 2010. Manajemen Keuangan Daerah 'seri: pemberdayaan akuntabilitas publik'. Erlangga : Jakarta.

Mardiasmo. 2002. Prinsip-Prinsip Manajemen Dalam Pembiayaan Desentralisasi. Yogyakarta: FE-UGM

Ni Luh Gede Astariyani. 2009. Pendelegasian Kewenangan Mengatur Dalam Peraturan Gubernur. Tesis. program Pasca sarjana Universitas Udayana : Bali

Peter Mahmud Marzuki. 2009. Penelitian Hukum . Kencana Predana Media Group : Jakarta.

Peter Drucker dalam Kisdarto. 2002. Menuju Sumber Daya Manusia Berdaya. Prestasi Pustaka Publisher : Jakarta

Philipus M Hadjon dan Tatiek Sri Djatmiati. 2005. Argumentasi Hukum. Gajah Mada University Press: Yogyakarta.

Philipus Hadjon Merancang dan Menulis Penelitian Hukum Normatif (Teori dan Filsafat), Universitas Airlangga : Surabaya .

Puteri Hikmawati. 2012. Sinkronisasi Dan hemonisasi Hukum Penyelenggaraan Otonomi Daerah Studi Di Provinsi Bali .

Ricky W Griffin. 2002. Manajemen (terj).. Erlangga: Jakarta.

Ridwan, HR. 2006. Hukum Administrasi Negara.UII Press: Yogyakarta.

Soedarmayanti. 2000. Restrukturisasi dan Pemberdayaan Organisasi untuk Menghadapi Dinamika Perubahan Lingkungan 